\title{
Clinical, cytogenetic, and molecular findings of isodicentric $Y$ chromosomes
}

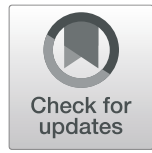

Yang Yang ${ }^{1}$ and Wang $\mathrm{HaO}^{1,2^{*}}$

\begin{abstract}
Background: Isodicentric $Y$ chromosomes [idic $(Y)$ ] are one of the most common structural abnormalities of the $Y$ chromosome. The prenatal diagnosis of isodicentric $Y$ chromosomes is of vital importance, and the postnatal phenotypes vary widely. Therefore, we present six patients prenatally diagnosed with isodicentric $Y$ chromosomes and review the literature concerning the genotype-phenotype correlations.

Method: The clinical materials of six patients were obtained. Cytogenetic and molecular approaches were carried out for these six patients.

Results: Isodicentric $Y$ chromosomes were found in all sixpatients. Among them, four patients presented with a mosaic 45,X karyotype, one patient had a 46,XY cell line, and one patient was nonmosaic. Five of these six isodicentric $Y$ chromosomes had a breakpoint in Yq11.2, and the other had a breakpoint in Yp11.3. The molecular analysis demonstrated different duplications and deletions of the $Y$ chromosome. Finally, three patients chose to terminate the pregnancy, two patients gave birth to normal-appearing males, and one patient was lost to followup.
\end{abstract}

Conclusion: The incorporation of multiple cytogenetic and molecular techniques would offer a more comprehensive understanding of this structural chromosomal abnormality for genetic counselling.

Keywords: Isodicentric Y chromosome, Fluorescence in situ hybridization, Chromosomal microarray analysis, Prenatal diagnosis, Mosaicism

\section{Background}

Isodicentric $\mathrm{Y}$ chromosomes $[\operatorname{idic}(\mathrm{Y})]$ were first identified by Jacobs et al. [1] and are commonly found in $\mathrm{Y}$ chromosome structural aberrations [2]. The formation of isodicentric $\mathrm{Y}$ chromosomes is believed to result from intrachromosomal recombination or the fusion between sister chromatids following the chromosomal break of the $\mathrm{Y}$ chromosome [3]. The sites where breakage and fusion occur at the Y chromosome vary greatly [4]. Thus, the isodicentric $\mathrm{Y}$ chromosome breakpoint would determine the Y material maintained, leading to highly variable duplications and deletions of the $\mathrm{Y}$ chromosome.

Isodicentric $\mathrm{Y}$ chromosomes are quite unstable due to the existence of two centromeres, resulting in various

\footnotetext{
* Correspondence: loster2010@outlook.com

'Prenatal Diagnosis Center, Hangzhou Maternity and Child Care Hospital, \#369 Kunpeng Road, Shangcheng District, Hangzhou 310008, Zhejiang, China

${ }^{2}$ Department of Cell Biology and Medical Genetics, School of Medicine, Zhejiang University, Hangzhou, Zhejiang, China
}

mosaicism [5]. The karyotypes of the mosaic cell lines depend on the origin where the isodicentric Y chromosomes arose and the instability of the altered chromosomes during meiosis or mitosis [6], and a 45,X cell line is the most common [7]. Patients with isodicentric $\mathrm{Y}$ chromosomes have a wide range of phenotypic manifestations, such as Turner syndrome in females [8], infertility in males [9], ambiguous genitalia [10], gonadal dysgenesis [11], short stature [12] and others. The phenotypes depend on the breakage and fusion of the isodicentric $\mathrm{Y}$ chromosomes, as well as the types and proportions of mosaicism [13].

Given that isodicentric Y chromosomes have great impacts on the genotypes and phenotypes of affected patients, a prenatal diagnosis is crucial. Several approaches, including cytogenetic and molecular techniques, are generally applied for the prenatal diagnosis of isodicentric $\mathrm{Y}$ chromosomes. The methods can be complementary to each other due to their own merits and limitations.

(c) The Author(s). 2019 Open Access This article is distributed under the terms of the Creative Commons Attribution 4.0 International License (http://creativecommons.org/licenses/by/4.0/), which permits unrestricted use, distribution, and reproduction in any medium, provided you give appropriate credit to the original author(s) and the source, provide a link to the Creative Commons license, and indicate if changes were made. The Creative Commons Public Domain Dedication waiver (http://creativecommons.org/publicdomain/zero/1.0/) applies to the data made available in this article, unless otherwise stated. 
Here, we present six patients with isodicentric Y chromosomes identified prenatally using different detection approaches to emphasize the importance of combining conventional cytogenetic analyses with molecular techniques in prenatal diagnosis. Furthermore, we reviewed the relevant literature aiming to better understand the genotype-phenotype correlations of isodicentric Y chromosomes for comprehensive genetic counselling.

\section{Methods}

\section{Subjects}

Six patients were referred to the Prenatal Diagnosis Centre of our hospital for various indications. Amniotic fluid samples were obtained from all patients, and cord blood was obtained from patient 6. All patients were informed of the test they were to complete. The clinical information of the patients is listed in Table 1 .

\section{Cytogenetic analysis}

Amniotic fluid and cord blood samples were obtained via transabdominal amniocentesis and cordocentesis under sterile circumstances. Amniotic fluid cells and cord blood lymphocytes were cultured and harvested according to standard protocols. G-band staining was applied for the preparation of the chromosome specimens. The karyotypes were reported in accordance with the up-to-date International System for Human Cytogenomics Nomenclature 2016 (ISCN2016).

\section{Fluorescence in situ hybridization (FISH) analysis}

FISH analysis was carried out using a sex-determining region $\mathrm{Y}(\mathrm{SRY}) / \mathrm{CEP} \mathrm{X}(\mathrm{DXZ1})$ probe and a CEP $\mathrm{Y}$ (DYZ3) probe (Vysis; Abbott Molecular, IL, USA) following the manufacturer's instructions. The SRY/DXZ1 probe specifically hybridizes with the sex-determining region of Yp11.3 and the $\mathrm{X}$ centromere. The DYZ3 probe is specific for the centromeric region of the $Y$ chromosome.

\section{Bacterial artificial chromosomes-on-beads assay}

The prenatal bacterial artificial chromosomes-on-beads (BoBs) assay was performed according to the manufacturer's protocol (PerkinElmer, MA, USA). The kit was designed for the aneuploidies of chromosomes 13, 18, and 21 and the sex chromosomes, as well as the detection of 9 microdeletion syndromes. The beads were analysed using the Luminex 200 platform (Luminex,TX, USA), and the data analysis was performed with BoBsoft 2.0 software (PerkinElmer, MA, USA).

\section{Chromosomal microarray analysis (CMA)}

The Affymetrix CytoScan $750 \mathrm{~K}$ gene chip (Affymetrix, CA, USA) was used for the CMA. It contains 200,000 single nucleotide polymorphism (SNP) probes and 550, 000 copy number variant (CNV) probes. The data were analysed using Chromosome Analysis Suite software (Affymetrix, CA, USA), and changes in CNVs, loss of heterozygosity $(\mathrm{LOH})$ and uniparental disomy (UPD) were identified.

\section{Results}

The cytogenetic analysis of cultured amniotic fluid samples from patient 1 revealed a 45,X [32]/46,X,idi$\mathrm{c}(\mathrm{Y})(\mathrm{q} 11.21)$ [1] karyotype (Fig. 1a). FISH analysis showed two SRY signals in 7 of 100 uncultured amniocytes, and no SRY signal was found in the remaining cells (Fig. 2a, b). The prenatal BoBs assay indicated microdeletions in the Yq11.223 region, which was consistent with the breakpoint in Yq11.2. Ultrasound examination indicated male genitalia. After a great deal of deliberation, the patient decided to terminate the pregnancy.

The karyotype of cultured amniocytes obtained from patient 2 was 46,X,?idic(Y) (Fig. 1b). FISH analysis of uncultured amniocytes confirmed the presence of an isodicentric Y chromosome with the breakpoint at Yp11.3 in all 50 cells counted (Fig. 2c). The SRY signals were closelylocated. Finally, the karyotype of the foetus was reported as 46,X,idic(Y)(p11.3).ish idic(Y)(p11.3)(SRY++). The patient decided to continue the pregnancy and gave birth to a phenotypically normal male.

The evaluation of G-banding chromosomes of amniocytes from patient 3 showed a mosaic karyotype of 46,X, $\operatorname{idic}(Y)(q 11.2)$ [59]/45,X [14] (Fig. 1c). FISH analysis revealed that $42 \%$ of the uncultured amniocytes had a 45 ,

Table 1 Clinical information of six patients with isodicentric $Y$ chromosomes

\begin{tabular}{llllll}
\hline Patient & Age (years) & Indication & Pregnancy history & Specimen & Laboratory test \\
\hline 1 & 36 & AMA & G2 P1 & AF & Karyotype, BoBs assay, FISH \\
2 & 34 & AMA & G2 P1 & AF & Karyotype, FISH \\
3 & 28 & NIPT abnormality & G2 P1 & AF & Karyotype, CMA, FISH \\
4 & 35 & NIPT abnormality & G2 P1 & AF & Karyotype, CMA \\
5 & 30 & MSS and NIPT abnormality & G2 P0 & AF & Karyotype, CMA \\
6 & 40 & AMA, IVF & G3 P1 & AF, CB & Karyotype, FISH \\
\hline
\end{tabular}

AMA Advanced maternal age, NIPT Non-invasive prenatal test, MSS Maternal serum screening, IVF In vitro fertilization, $A F$ Amniotic fluid, $C B$ Cord blood, BoBs Bacterial artificial chromosomes-on-beads, FISH Fluorescence in situ hybridization, CMA Chromosomal microarray analysis 
A

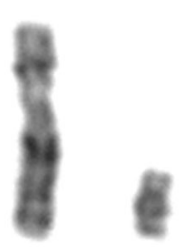

D

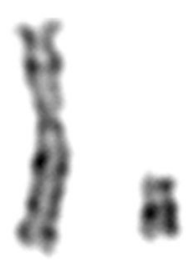

B



E



C

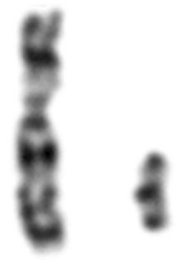

F

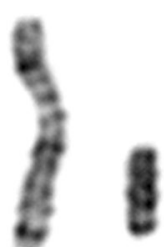

Fig. 1 Partial karyotypes of $X$ and $Y$ chromosomes for the six patients. All the $Y$ chromosomes are isodicentric and placed on the right. a Patient 1: $\operatorname{idic}(Y)(q 11.21)$. b Patient 2: $\operatorname{idic}(Y)(p 11.3)$. c Patient 3: $\operatorname{idic}(Y)(q 11.2)$. d Patient 4: idic(Y)(q11.22). e Patient 5: idic(Y) (q11.2). f Patient 6: $\operatorname{idic}(Y)(q 11.2)$

$\mathrm{X}$ karyotype, $38 \%$ of the counted cells contained an isodicentric Y chromosome, and $20 \%$ of the cells showed a normal male karyotype (Fig. 2d, e, f, g). The CMA of the amniotic fluid sample suggested a $19.4 \mathrm{Mb}$ duplication of the Yp11.32q11.221 segment and a $38.7 \mathrm{Mb}$ deletion of the Yq11.222q12 segment. This finding confirmed the breakpoint in Yq11.2. The peripheral blood of the foetus's father was also obtained, and no abnormality of the
Y chromosome was found in the karyotype analysis. Termination of the pregnancy was performed after genetic counselling.

Regarding patient 4 , the karyotype of cultured amniocytes was mos 45,X [17]/46,X, idic(Y)(q11.22) [9] (Fig. 1d). The CMA of the amniotic fluid specimen indicated a $17.9 \mathrm{Mb}$ duplication of the Yp11.31q11.222 segment and a $7.7 \mathrm{Mb}$ deletion of the Yq11.222q11.23 segment.



Fig. 2 FISH analysis for patients 1, 2, 3, and 6. Patient 1: the SRY/DXZ1 probe was used. a Only one DXZ1 (green) signal was observed, indicating a 45,X karyotype. b Two SRY (red) signals and one DXZ1 (green) signal were observed, suggesting a 46,X,idic(Y) karyotype. Patient 2: the SRY/ DXZ1 probe was used. c Two proximal SRY signals are shown in red, revealing that the breakpoint of this isodicentric $Y$ chromosome was in the short arm of the Y chromosome. Patient 3: The different patterns of SRY (red) and DXZ1 (green) signals in (d), (e), and (f) suggested mosaicism of $45, X / 46, X, i d i c(Y) / 46, X Y$. $g$ The DYZ3 probe was also applied to patient 3. One DYZ3 (red) centromeric signal was constricted while the other one was not, indicating that one centromere was inactivated. Patient 6: h Two DYZ3 (red) signals were observed at the isodicentric $Y$ chromosome 
The pregnancy was continued, and the infant was an apparently normal male at birth.

The karyotype of cultured amniocytes of patient 5 was mos 45,X [26]/46,X,idic(Y)(q11.2) [5] (Fig. 1e). A 16.9 $\mathrm{Mb}$ duplication of the Yp11.31q11.221 segment and an $8.1 \mathrm{Mb}$ deletion of the Yq11.222q11.23 segment were found in the CMA of the amniotic fluid. The patient chose to terminate the pregnancy based on the results.

The karyotypes of amniotic fluid and cord blood from patient 6 were 46,X,idic $(\mathrm{Y})(\mathrm{q} 11.2)$ [17]/46,XY [15] and $46, \mathrm{X}, \operatorname{idic}(\mathrm{Y})(\mathrm{q} 11.2)$, respectively. This isodicentric $\mathrm{Y}$ chromosome is displayed in Fig. 1f. FISH analysis was applied to the cultured suspension of cord blood to confirm that the derivative $\mathrm{Y}$ chromosome had two visible centromeres (Fig. 2h). Patient 6 was lost to follow-up, and thus, the clinical outcome for her foetus was not obtained.

\section{Discussion}

Isodicentric Y chromosomes are frequently observed in $\mathrm{Y}$ chromosome structural abnormalities [2]. This Y chromosome aberration involves the breakage and fusion of the $\mathrm{Y}$ chromosome, which leads to the gain and loss of $\mathrm{Y}$ chromosome material. As the $\mathrm{Y}$ chromosome contains various genes involved in sex determination, spermatogenesis, growth and development, deletions and duplications of the $\mathrm{Y}$ chromosome would probably cause multiple malformations and dysfunctions in the affected individual. Thus, it is extremely important to identify this $\mathrm{Y}$ chromosome aberration prenatally to provide genetic counselling and interpretation. Previous studies have applied conventional karyotype analysis, FISH, Southern blot, and sequence-tagged site (STS) PCR to identify isodicentric Y chromosomes and the breakpoints contained within them $[14,15]$. Other techniques, such as multiplex ligation-dependent probe amplification (MLPA), qPCR, CMA, and the sequencing of certain genes, have also been used to gain molecular insight into isodicentric Y chromosomes [16-18]. In this study, we used different methods for the detection of isodicentric $\mathrm{Y}$ chromosomes and found that they could be complementary to each other. Because of the limitation of each technique, using one single method to identify isodicentric $\mathrm{Y}$ chromosomes could be quite risky, especially when it coexists with other cell lines. A combination of cytogenetic and molecular analysis would provide detailed information on the gain and loss of isodicentric Y chromosomes, assisting in the interpretations of the test results [19]. However, inconsistent results might arise in cases of very complicated mosaicism, which require apanoramic view of the results in a retrospective manner [17]. Additionally, cryptic mosaics make it even more difficult to identify small supernumerary marker chromosomes [20]. Researchers have established pericentromeric-critical region FISH probe sets to better characterize small supernumerary marker chromosomes that are also applied to isodicentric $\mathrm{Y}$ chromosomes [21].

Because of the existence of two centromeres in isodicentric $\mathrm{Y}$ chromosomes, it is difficult for this derivative chromosome to remain stable. Researchers have noted that isodicentric Y chromosomes can achieve stabilization via the inactivation of one centromere, and the active centromere, which is constricted, would bind to the mitotic spindles [22]. This is consistent with the findings of our study. Nonetheless, isodicentric Y chromosomes appear to be either monocentric ordicentric depending on the intercentromeric distance [22]. If the intercentromeric distance is small enough, the two active centromeres could behave as one centromere [23]. In some cases, isodicentric $\mathrm{Y}$ chromosomes with one or two constrictions could coexist in one specimen [24]. Given the instability of isodicentric Y chromosomes, they frequently appear as highly mosaic [23]. In our study, only one of the six patients had a nonmosaic karyotype, and a 45,X cell line was most common form of mosaicism. These findings are consistent with most isodicentric $\mathrm{Y}$ chromosome cases reported $[4,11,14$, 25-29]. There are also many other aberrant chromosomes that could arise with isodicentric $\mathrm{Y}$ chromosomes, leading to a very complicated karyotype $[3,4,17,30$ 32]. This mosaicism might be related to the time (i.e., during meiosis or postzygote) during which the isodicentric Y chromosome originated, instability during mitosis, and whether other chromosomes were involved [23]. Dynamic mosaicism could make the karyotypes even more variable [32].

Patients carrying isodicentric $\mathrm{Y}$ chromosomes often come to medical attention when certain abnormal manifestations emerge. The prenatal diagnosis of isodicentric $Y$ chromosomes is less common than the postnatal diagnosis of isodicentric $Y$ chromosomes [33]. The prenatally diagnosed foetuses with isodicentric $\mathrm{Y}$ chromosomes are listed in Table 2. Most were phenotypical males, even carrying a 45,X cell line. 45,X cell lines predominated in the amniotic fluid karyotypes of the two females but presented lower proportions in the cord blood $[34,36]$. A discrepancy between mosaicism from different tissues has generally been recognized in other cases $[9,11,18$, 43-45], which might have been caused by the different origins of the tissues and could be affected by the biases of subcultures and counting. Therefore, we could not determine the accurate percentage of a $45, \mathrm{X}$ cell line to indicate the phenotypical sex of the foetuses. Even if the foetus was male, the percentage of a $45, \mathrm{X}$ cell line could be rather high, as we observed in patient 1 . The low percentage of isodicentric $\mathrm{Y}$ chromosomes in patient 1 could have been missed if it were not for the ultrasound 
Table 2 Summary of patients prenatally diagnosed with isodicentric $Y$ chromosomes

\begin{tabular}{|c|c|c|c|c|c|}
\hline Patient & Tissue & Karyotype & Clinical outcome & Sex & Reference \\
\hline \multirow[t]{2}{*}{1} & AF & 47,X,idic(Y)(q11.21),inv. dup(Y) & \multirow[t]{2}{*}{ Phenotypically normal } & \multirow[t]{2}{*}{ M } & \multirow[t]{2}{*}{ [3] } \\
\hline & PB & & & & \\
\hline 2 & AF & 46,X,idic(Y)(q11.23) & Phenotypically normal & M & [23] \\
\hline 3 & AF & $46, X, \operatorname{del}(Y)(q 12) / 45, X / 46, X, \operatorname{idic}(Y)(q 11.22)$ & Unknown & M & [17] \\
\hline 4 & AF & 46,X,idic(Y)(q11.23) [41]/45,X [22] & Phenotypically normal & M & {$[5]$} \\
\hline \multirow[t]{5}{*}{5} & $A F$ & $45, X[54] / 46, X, \operatorname{idic}(Y)(p 11.3)[8] / 46, X Y[3]$ & \multirow{5}{*}{$\begin{array}{l}\text { Defect in the interventricular septum } \\
\text { of the heart }\end{array}$} & \multirow[t]{5}{*}{ M } & \multirow[t]{5}{*}{ [18] } \\
\hline & $\begin{array}{l}\text { Antenatal } \\
\mathrm{CB}\end{array}$ & 45,X [24]/46,X,idic(Y)(p11.3) [26] & & & \\
\hline & $\begin{array}{l}\text { Placental } \\
\text { villi }\end{array}$ & $45, X[89] / 46, X, \operatorname{idic}(Y)(p 11.3)[11]$ & & & \\
\hline & $\begin{array}{l}\text { Postnatal } \\
\text { CB }\end{array}$ & $45, X[87] / 46, X, \operatorname{idic}(Y)(p 11.3)[10] / 46, X Y$ [3] & & & \\
\hline & Gonad & 45,X [45]/46,X,idic(Y)(p11.3) [55] & & & \\
\hline \multirow[t]{2}{*}{6} & AF & $45, X$ & \multirow[t]{2}{*}{ Termination } & \multirow[t]{2}{*}{$\mathrm{F}$} & \multirow[t]{2}{*}[34]{} \\
\hline & $\mathrm{CB}$ & $45, X(20 \%) / 46, X, \operatorname{idic}(Y)(p 11)(80 \%)$ & & & \\
\hline 7 & AF & $45, X[27] / 46, X, \operatorname{idic}(Y)(q 11.22)[14]$ & Termination & M & [19] \\
\hline \multirow[t]{4}{*}{8} & PB & $45, X[23] / 46, X, \operatorname{idic}(Y)[8]$ & \multirow{4}{*}{$\begin{array}{l}\text { Complex heart lesion, generalized } \\
\text { oedema, died } 19 \text { days after birth }\end{array}$} & \multirow[t]{4}{*}{ A } & \multirow[t]{4}{*}{ [35] } \\
\hline & $\begin{array}{l}\text { Right } \\
\text { Gonad }\end{array}$ & $45, X[47] / 46, X, \operatorname{idic}(Y)[3]$ & & & \\
\hline & Left Gonad & 45,X [44]/46,X,idic(Y) [6] & & & \\
\hline & AF & $45, X$ & & & \\
\hline \multirow[t]{2}{*}{9} & AF & $45, X[28] / 46, X, \operatorname{idic}(Y)(q 11.2)[2]$ & \multirow[t]{2}{*}{ Phenotypically normal } & \multirow[t]{2}{*}{$\mathrm{F}$} & \multirow[t]{2}{*}{ [36] } \\
\hline & $\mathrm{CB}$ & $46, X, \operatorname{idic}(Y)(q 11.2)[31] / 45, X[17] / 47, X, \operatorname{idic}(Y) \times 2[2]$ & & & \\
\hline 10 & AF & $46, X, \operatorname{idic}(Y)[3] / 45, X[2] / 46, X Y[24]$ & Phenotypically normal & M & [25] \\
\hline \multirow[t]{2}{*}{11} & AF & $45, X[2] / 46, X Y[13]$ & \multirow[t]{2}{*}{ Phenotypically normal } & \multirow[t]{2}{*}{ M } & \multirow[t]{2}{*}[25]{} \\
\hline & PB & $46, X, \operatorname{idic}(Y)(q 10)[5] / 46, X Y[95]$ & & & \\
\hline \multirow[t]{2}{*}{12} & $\begin{array}{l}\text { Chorionic } \\
\text { villi }\end{array}$ & $45, X[11] / 46, X Y[9]$ & \multirow[t]{2}{*}{ Phenotypically normal } & M & [25] \\
\hline & AF & $46, X, \operatorname{idic}(Y)(q 11)[4] / 45, X[1] / 46, X Y[26]$ & & & \\
\hline 13 & AF & $46, X, \operatorname{idic}(Y)(q 10)[26] / 45, X[3] / 47, X, i(Y),+i(Y)[2]$ & Phenotypically normal & M & [25] \\
\hline & PB & $46, X, \operatorname{idic}(Y)(q 11)[95] / 45, X[5]$ & & & \\
\hline 14 & AF & 46,X,idic(Y)(q11.2) [17] & Phenotypically normal & M & [25] \\
\hline & PB & $46, X, \operatorname{idic}(Y)(q 11.2)[50]$ & & & \\
\hline & Chorion & $46, X, \operatorname{idic}(Y)(q 11.2)[27] / 45, X[3]$ & & & \\
\hline 15 & AF & $45, X / 46, X, \operatorname{idic}(Y)(q 11.2) / 47, X, \operatorname{idic}(Y)(q 11.2),+\operatorname{idic}(Y)(q 11.2)$ & Phenotypically normal & M & [25] \\
\hline & $\mathrm{PB}$ & $46, X, \operatorname{idic}(Y)(q 11.2)[18] / 45, X[14]$ & & & \\
\hline 16 & AF & $46, \mathrm{idic}(Y)(q 11.2)[13] / 45, X[6]$ & Phenotypically normal & M & [25] \\
\hline & PB & $46, X, \operatorname{idic}(Y)(q 11.2)[8] / 45, X[2]$ & & & \\
\hline 17 & AF & $46, X, \operatorname{idic}(Y)(q 11.2)[22] / 45, X[7]$ & Normal genitalia at termination & M & [25] \\
\hline & Chorion & $46, X, \operatorname{idic}(Y)(q 11.1)[8]$ & & & \\
\hline 18 & AF & $46, X, \operatorname{idic}(Y)[22] / 45, X[5]$ & Phenotypically normal & M & [25] \\
\hline 19 & AF & $45, X[12] / 46, X Y[17]$ & Phenotypically normal & M & [25] \\
\hline & Amnion & $45, X[2] / 46, X Y[11]$ & & & \\
\hline & PB & 46,X,idic(Y)(q11.2) [17]/45,X [3]/46,X,?r(Y) [2] & & & \\
\hline 20 & AF & $45, X[10]$ & Normal genitalia at termination & M & [25] \\
\hline
\end{tabular}


Table 2 Summary of patients prenatally diagnosed with isodicentric $Y$ chromosomes (Continued)

\begin{tabular}{|c|c|c|c|c|c|}
\hline Patient & Tissue & Karyotype & Clinical outcome & Sex & Reference \\
\hline \multirow[t]{3}{*}{21} & $\mathrm{AF}$ & $45, X[10]$ & \multirow{3}{*}{$\begin{array}{l}\text { Ambiguous genitalia, short } \\
\text { stature }\end{array}$} & \multirow[t]{3}{*}{ A } & \multirow[t]{3}{*}{ [25] } \\
\hline & PB & 45,X/46,X,idic(Y)(q11.2) & & & \\
\hline & Skin & 45,X/46,X,idic(Y)(q11.2)/46,X,?r(Y) & & & \\
\hline 22 & $\mathrm{AF}$ & $45, X,[14] / 46, X, p s u \operatorname{dic}(Y)(q 12)[5]$ & Phenotypically normal & M & [27] \\
\hline 23 & AF & 45,X [3]/46,X,idic(Y)(p11) [11] & Phenotypically normal & M & [27] \\
\hline 24 & $\mathrm{AF}$ & $45, X[2] / 46, X, \operatorname{idic}(Y p)[14]$ & $\begin{array}{l}\text { Normal genitalia at } 9 \text { years, } \\
\text { coarctation of the aorta }\end{array}$ & M & [27] \\
\hline \multirow[t]{2}{*}{25} & PB & $46, X, \operatorname{idic}(Y)(q 11.21)$ & \multirow[t]{2}{*}{ Mild language delay } & \multirow[t]{2}{*}{ M } & \multirow[t]{2}{*}{ [7] } \\
\hline & $\mathrm{AF}$ & $46, X, \operatorname{idic}(Y)(q 11.21)$ & & & \\
\hline 26 & AF & $45, X[14] / 46, X, i d i c(Y)(q 11.2)[86]$ & $\begin{array}{l}\text { Unilateral renal agenesis, } \\
\text { normal genitalia }\end{array}$ & M & [37] \\
\hline \multirow[t]{3}{*}{27} & AF & $\begin{array}{l}\text { 45,X [15]/46,X,idic(Yp) [6]/46,X,?del(Y)(q12) [2]/47,X, } \\
\text { ?del(Y)(q12)+?del(Y)(q12) [2] }\end{array}$ & \multirow[t]{3}{*}{ Termination } & \multirow[t]{3}{*}{-} & \multirow[t]{3}{*}{ [38] } \\
\hline & Foetal heart & $45, X[12] / 46, X, \operatorname{dic}(Y p)[9] / 46, X, ? \operatorname{del}(Y)(q 12)[4]$ & & & \\
\hline & $\begin{array}{l}\text { Foetal } \\
\text { kidney }\end{array}$ & $\begin{array}{l}\text { 45,X [19]/46,X,idic(Yp) [3]/46,X,?del(Y)(q12) [2]/47,X, } \\
\text { ?del(Y)(q12)+?del(Y)(q12) [1] }\end{array}$ & & & \\
\hline 28 & $\mathrm{AF}$ & $45, X / 46, X, \operatorname{idic}(Y)$ & Phenotypically normal & M & [39] \\
\hline 29 & $\mathrm{AF}$ & $45, X / 46, X, \operatorname{idic}(Y)$ & Phenotypically normal & M & [39] \\
\hline \multirow[t]{6}{*}{30} & AF & $45, X[125] / 46, X, \operatorname{dic}(Y)(q 11)[5]$ & \multirow{6}{*}{$\begin{array}{l}\text { Abdominal wall defect, } \\
\text { mild chordee of the penis }\end{array}$} & \multirow[t]{6}{*}{ M } & \multirow[t]{6}{*}{ [40] } \\
\hline & PB & $45, X[14] / 46, X, \operatorname{dic}(Y)(q 11)[16]$ & & & \\
\hline & Skin & $45, X[15] / 46, X, \operatorname{dic}(Y)(q 11)[15]$ & & & \\
\hline & Placenta A & $45, X[4] / 46, X, \operatorname{dic}(Y)(q 11)[30]$ & & & \\
\hline & Placenta B & $45, X[20] / 46, X, \operatorname{dic}(Y)(q 11)[10]$ & & & \\
\hline & Placenta C & $45, X[12] / 46, X, \operatorname{dic}(Y)(q 11)[18]$ & & & \\
\hline \multirow[t]{2}{*}{31} & AF & $45, X[8] / 46, X, \operatorname{idic}(Y)(p 11.32)[2]$ & \multirow[t]{2}{*}{ Phenotypically normal } & \multirow[t]{2}{*}{ M } & \multirow[t]{2}{*}{ [41] } \\
\hline & PB & $45, X[27] / 46, X, \operatorname{idic}(Y)[1]$ & & & \\
\hline 32 & PB & $45, X / 46, X, \operatorname{idic}(Y)(q 11.2)$ & Unknown & $\mathrm{F}$ & [42] \\
\hline
\end{tabular}

AF Amniotic fluid, $C B$ Cord blood, $P B$ Peripheral blood, $M$ Male, F Female, $A$ Ambiguous

result. Thus, the ultrasound determination of the phenotypical sex of the foetuses could aid in the cytogenetic analysis [36]. The patients described in Table 2 and our patients showed that most isodicentric Y chromosomes found prenatally had similar breakpoints in Yq11.2 and Yp11.3, but the breakpoints had no direct correlation with the phenotypes at birth or termination. As listed in Table 2, some foetuses presented normal phenotypes, while others showed various defects because of the gain and loss of genetic material. Considering that the followup was not longterm, abnormalities might arise during puberty. Clinical management will be very important along with the growth and development of the affected individuals.

The most common clinical manifestations of patients with isodicentric $\mathrm{Y}$ chromosomes are stigmata of Turner syndrome, gonadal dysgenesis, ambiguous genitalia, growth and mental retardation, azoospermia, infertility and others $[4,8-12,16,28-30,35,41,42]$. The phenotypes are related to the breakpoints of isodicentric $\mathrm{Y}$ chromosomes, mosaicism, and distributions of cell lines in different tissues [13]. Isodicentric Y chromosomes would lose segments from the breakpoints to the distal ends and gain partial disomy of the segments maintained. Y chromosomes are more likely to break in common fragile AT-rich sites [46]. Patients with isodicentric $\mathrm{Y}$ chromosomes showing symptoms of Turner syndrome often carry a 45,X cell line [4]. The SRY gene is located at Yp11.32 and is critical for the development of secondary sexual characteristics in males [47]. Yp11.32 is a very common breakpoint in isodicentric $\mathrm{Y}$ chromosomes [48-51]. However, the copy number of the SRY gene could not determine the phenotype of the patient due to the coexistence of other cell lines. Some patients with two copies of the SRY gene on isodicentric Y chromosomes still had ambiguous genitalia resulting from mosaicism [11]. The azoospermia and infertility observed in patients with isodicentric $\mathrm{Y}$ chromosomes were primarily associated with breakpoints in Yq, leading to deletions and rearrangements of azoospermia factor (AZF) 
loci (AZFa, AZFb, and AZFc) [52]. These three loci are all involved in spermatogenesis, and the loss of any locus would cause oligozoospermia or azoospermia [53]. However, some researchers reported that a patient without AZF deletions demonstrated azoospermia possibly due to other Y chromosome structural abnormalities or mosaicism [54]. Yp11.32 also contains the short stature homeobox (SHOX) gene, which participates in the proliferation and differentiation of chondrocytes [55] and hence growth retardation in affected patients. Some patients showed features of Klinefelter syndrome resulting from extra Y chromosome material [31, 56, 57]. A few researchers found a potential correlation between isodicentric Y chromosomes and susceptibility to schizophrenia [58], but the evidence was not strong enough [59]. There are some other rare defects that occur in patients carrying isodicentric $\mathrm{Y}$ chromosomes, such as Moyamoya disease, aortic dissection, and congenital heart disease $[18,35,60,61]$. These are either coincidences or consequences of the altered dosage of sex chromosome genes [60, 61]. Individual differences in development also play a vital role in the clinical manifestations of patients [62-64]. In general, it is still difficult to conclude a precise genotype-phenotype relationship.

Once isodicentric $\mathrm{Y}$ chromosomes are identified in affected patients, medical interventions should be proposed. Patients with a short stature could achieve nearadult height with growth hormone therapy from an early age [33]. Female patients carrying isodicentric $Y$ material in the gonads are at great risk of gonadoblastoma, especially after puberty; thus, prophylactic gonadectomy is strongly recommended [65-67]. Foetuses showing ambiguous genitalia should be assigned a certain sex after a thorough evaluation of the genital anomalies [68]. Because patients carrying isodicentric $\mathrm{Y}$ chromosomes often present with complex manifestations, a long-term follow-up and clinical management are of great importance.

In conclusion, we reported six patients prenatally diagnosed with isodicentric $\mathrm{Y}$ chromosomes using cytogenetic and molecular techniques. Because isodicentric $\mathrm{Y}$ chromosomes often present with mosaicism, we need to be careful when addressing these cases. The application of multiple methods to identify isodicentric $\mathrm{Y}$ chromosomes could not only serve as confirmation but also provide more detailed information of the derivative chromosomes for genetic counselling. Clinical information such as ultrasound results could help uncover low mosaics of isodicentric $\mathrm{Y}$ chromosomes. A long-term follow-up would help shed light on the genotypephenotype relationship of isodicentric Y chromosomes.

Acknowledgements

Not applicable.
Authors' contributions

YY acquired the clinic data and drafted the manuscript. WH analyzed and interpreted the patient data. Both authors read and approved the final manuscript.

\section{Funding}

Not applicable.

\section{Availability of data and materials}

The datasets used and/or analysed during the current study are available from the corresponding author on reasonable request.

\section{Ethics approval and consent to participate}

This study is retrospective and did not require the ethical approval.

Consent for publication

The patients had provided their consent for publication.

\section{Competing interests}

The authors declare that they have no competing interests.

Received: 3 July 2019 Accepted: 11 December 2019

Published online: 27 December 2019

\section{References}

1. Jacobs PA, Ross A. Structural abnormalities of the $Y$ chromosome in man. Nature. 1966;210(5034):352-4.

2. Hsu LY. Phenotype/karyotype correlations of $Y$ chromosome aneuploidy with emphasis on structural aberrations in postnatally diagnosed cases. Am Jed Genet. 1994;53(2):108-40.

3. Pasantes JJ, Wimmer R, Knebel S, Munch C, Kelbova C, Junge A, et al. $47, X, \operatorname{idic}(Y)$,inv dup(Y): a non-mosaic case of a phenotypically normal boy with two different $Y$ isochromosomes and neocentromere formation. Cytogenet Genome Res. 2012;136(2):157-62.

4. Robinson DO, Dalton $\mathrm{P}$, Jacobs PA, Mosse $\mathrm{K}$, Power MM, Skuse DH, et al. A molecular and FISH analysis of structurally abnormal $Y$ chromosomes in patients with turner syndrome. J Med Genet. 1999;36(4):279-84.

5. Bergeron MB, Brochu P, Lemyre $E$, Lemieux N. Correlation of intercentromeric distance, mosaicism, and sexual phenotype: molecular localization of breakpoints in isodicentric Y chromosomes. Am J Med Genet A. 2011;155(11):2705-12.

6. Stankiewicz P, Helias-Rodzewicz Z, Jakubow-Durska K, Bocian E, Obersztyn E, Rappold GA, et al. Cytogenetic and molecular characterization of two isodicentric Y chromosomes. Am J Med Genet. 2001;101(1):20-5.

7. DesGroseilliers M, Beaulieu Bergeron M, Brochu P, Lemyre E, Lemieux N. Phenotypic variability in isodicentric $Y$ patients: study of nine cases. Clin Genet. 2006;70(2):145-50.

8. Bagci G, Acar H, Tomruk H. Different chromosome $Y$ abnormalities in Turner syndrome. Genet Couns. 2001;12(3):255-61.

9. Bettio D, Venci A, Rizzi N, Negri L, Setti PL. Clinical and molecular cytogenetic studies in three infertile patients with mosaic rearranged $Y$ chromosomes. Hum Reprod. 2006;21(4):972-5.

10. Pascual J, McMann LP, Gallagher T, Pinsker JE. Ambiguous genitalia in a newborn with 45,X/46,X,idic(Y) ovotesticular disorder of sex development. Endocr Pract. 2009;15(7):732-6.

11. Kaprova-Pleskacova J, Snajderova M, Stoop J, Koudova M, Kocarek E, Novotna $D$, et al. 45,X/46,X,psu $\operatorname{dic}(Y)$ gonadal dysgenesis: influence of the two cell lines on the clinical phenotype, including gonadal histology. Sex Dev. 2013;7(6):282-8.

12. Giltay JC, Ausems MG, van Seumeren I, Zewald RA, Sinke RJ, Faas B, et al. Short stature as the only presenting feature in a patient with an isodicentric (Y)(q11.23) and gonadoblastoma. A clinical and molecular cytogenetic study. Eur J Pediatr. 2001;160(3):154-8.

13. Tuck-Muller CM, Chen H, Martinez JE, Shen CC, Li S, Kusyk C, et al. Isodicentric $Y$ chromosome: cytogenetic, molecular and clinical studies and review of the literature. Hum Genet. 1995:96(1):119-29.

14. Teraoka M, Narahara K, Yokoyama Y, Tsuji K, Kikkawa K, Ito S, et al. 45,X/ 46,X,idic(Yq) mosaicism: clinical, cytogenetic, and molecular studies in four individuals. Am J Med Genet. 1998;78(5):424-8.

15. Speleman F, Van der Auwera B, Mangelschots $K$, Vercruyssen M, Raap T, Wiegant J, et al. Identification and characterization of normal length 
nonfluorescent $Y$ chromosomes: cytogenetic analysis, southern hybridization and non-isotopic in situ hybridization. Hum Genet. 1990;85(6): 569-75

16. Castro A, Rodriguez F, Florez M, Lopez P, Curotto B, Martinez D, et al. Pseudoautosomal abnormalities in terminal $\mathrm{AZFb}+\mathrm{C}$ deletions are associated with isochromosomes Yp and may lead to abnormal growth and neuropsychiatric function. Hum Reprod. 2017;32(2):465-75.

17. Lin SY, Lee CN, Peng AY, Yuan TJ, Lee DJ, Lin WH, et al. Application of molecular cytogenetic techniques to characterize the aberrant $Y$ chromosome arising de novo in a male fetus with mosaic $45, \mathrm{X}$ and solve the discrepancy between karyotyping, chromosome microarray, and multiplex ligation dependent probe amplification. J Formos Med Assoc. 2018;117(11):1027-31.

18. Wu HH, Lee $T H$, Chen CD, Yeh KT, Chen M. Delineation of an isodicentric $Y$ chromosome in a mosaic 45,X/46,X,idic(Y)(qter-p11.3::p11.3-qter) fetus by SRY sequencing, G-banding, FISH, SKY and study of distribution in different tissues. J Formos Med Assoc. 2007;106(5):403-10.

19. Liu Y, Guo L, Chen H, Lu J, Hu J, Li X, et al. Discrepancy of QF-PCR, CMA and karyotyping on a de novo case of mosaic isodicentric $Y$ chromosomes. Molecular Cytogenet. 2019;12:1

20. Liehr T, Klein E, Mrasek K, Kosyakova N, Guilherme RS, Aust N, et al. Clinical impact of somatic mosaicism in cases with small supernumerary marker chromosomes. Cytogenet Genome Res. 2013;139(3):158-63.

21. Al-Rikabi ABH, Pekova S, Fan X, Jancuskova T, Liehr T. Small supernumerary marker chromosome may provide information on dosage-insensitive Pericentric regions in human. Curr Genomics. 2018;19(3):192-9.

22. Lange J, Skaletsky H, van Daalen SK, Embry SL, Korver CM, Brown LG, et al. Isodicentric $Y$ chromosomes and sex disorders as byproducts of homologous recombination that maintains palindromes. Cell. 2009;138(5):855-69.

23. Kuan LC, Su MT, Chen M, Kuo PL, Kuo TC. A non-mosaic isodicentric Y chromosome resulting from breakage and fusion at the $\mathrm{Yq}$ pseudoautosomal region in a fetus. J Assist Reprod Genet. 2013;30(12):1559-62.

24. Daniel A, Lyons N, Casey JH, Gras L. Two dicentric Y isochromosomes, one without and the Yah heterochromatic segment: review of the $Y$ isochromosomes. Hum Genet. 1980;54(1):31-9.

25. Bruyere $H$, Speevak MD, Winsor EJ, de Freminville B, Farrell SA, McGowanJordan J, et al. IsodicentricYp: prenatal diagnosis and outcome in 12 cases. Prenat Diagn. 2006;26(4):324-9.

26. Soares H, Maia A, Campos M, Doria S, Lopes JM, Fontoura M. Clinicopathological features of $45, \mathrm{X} / 46, \mathrm{Xidic}(\mathrm{Y})$ mosaicism and therapeutic implications: case report. Sao Paulo Med J. 2008;126(5):297-9.

27. Willis MJ, Bird LM, Dell'aquilla M, Jones MC. Natural history of prenatally diagnosed 46,X,isodicentric Y. Prenat Diagn. 2006;26(2):134-7.

28. Tran CN, Semins MJ, Epstein Jl, Gearhart JP. Ovotesticular disorder of sex development with mosaic 45,X/46,X,idic(Y) (q11.23) karyotype and streak gonad. Urology. 2011;78(5):1178-81.

29. Neas KR, Yip MY, James $C$, Kirk EP. Patient with a non-mosaic isodicentric Yp and mild developmental delay. Am J Med Genet A. 2005;137(2):223-4.

30. Dundar M, Lowther G, Acar H, Kurtoglu S, Demiryilmaz F, Kucukaydin M. A case of ambiguous genitalia presenting with a 45,X/46,Xr(Y)(p11.2; 11.23$) /$ 47,X,idic(Y)(p11.2),idic(Y)(p11.2) karyotype. Ann Genet. 2001;44(1):5-8.

31. Tomomasa H, Ogawa K, Nagasawa J, Satoh S, Muramatsu H, liyama T, et al. A case of mosaic Klinefelter syndrome associated with isodicentricYp. Reprod Med Biol. 2008;7(4):177-80.

32. lourov IY, Vorsanova SG, Liehr T, Monakhov W, Soloviev IV, Yurov YB. Dynamic mosaicism manifesting as loss, gain and rearrangement of an isodicentric $Y$ chromosome in a male child with growth retardation and abnormal external genitalia. Cytogenet Genome Res. 2008;121(3-4):302-6.

33. Guevarra FM, Nimkarn S, New MI, Lin-Su K. Long-term growth hormone therapy in an adolescent boy with 45,X/46,XidicY(p11). The Journal of pediatrics. 2009;155(5):752-5.

34. Gole LA, Anandakumar C, Yang R, Chan J, Wong YC, Bongso A. Discrepancy between cytogenetic and FISH results on an amniotic fluid sample of $45, \mathrm{X} /$ 46,X,idic(Y)(p11). Fetal Diagn Ther. 2000;15(4):212-5.

35. Atkins KE, Gregg A, Spikes AS, Bacino CA, Bejjani BA, Kirkland J, et al. Identification of $Y$ chromatin directly in gonadal tissue by fluorescence in situ hybridization (FISH): significance for Ullrich-turner syndrome screening in the cytogenetics laboratory. Am J Med Genet. 2000;91(5):377-82.

36. $\mathrm{Xu}$ J, Siu VM. Is there a correlation between the proportion of cells with isodicentricYp at amniocentesis and phenotypic sex? Prenat Diagn. 2010; 30(9):839-44.
37. Hernando C, Carrera M, Ribas I, Parear N, Baraibar R, Egocue J, et al. Prenatal and postnatal characterization of $Y$ chromosome structural anomalies by molecular cytogenetic analysis. Prenat Diagn. 2002;22(9):802-5.

38. Bernstein R, Steinhaus KA, Cain MJ. Prenatal application of fluorescent in situ hybridization (FISH) for identification of a mosaic Y-chromosome marker, idic(Yp). Prenat Diagn. 1992;12(9):709-16.

39. Huang B, Thangavelu M, Bhatt S, Sandlin C, Wang S. Prenatal diagnosis of $45, X$ and 45,X mosaicism: the need for thorough cytogenetic and clinical evaluations. Prenat Diagn. 2002;22(2):105-10.

40. Roland B, Cox DM, Rudd NL. Sex chromosome mosaicism not detected at amniocentesis. Prenat Diagn. 1990;10(5):333-6.

41. Marcus-Soekarman D, Hamers G, Mulder AL, Offermans J, Offermans J, Engelen J, et al. Sonographic genital ambiguity in a fetus due to a mosaic 45,X/46,X,idic(Y)(qter-p11.32:.p11.32-qter) karyotype. Prenat Diagn. 2005; 25(4):279-82.

42. Liehr T, Mrasek K, Hinreiner S, Reich D, Ewers E, Bartels I, et al. Small supernumerary marker chromosomes (sSMC) in patients with a $45, \mathrm{X} / 46, \mathrm{X}_{1}+$ mar karyotype - 17 new cases and a review of the literature. Sex Dev. 2007; 1(6):353-62.

43. Raff $R$, Schubert $R$, Schwanitz $G$, van der Ven $K$, Bruhl P. Combination of hypospadias and maldescended testis as cardinal symptoms in gonosomal chromosome aberrations. Eur J Pediatr Surg. 2000;10(4):270-5.

44. Guedes AD, Bianco B, Lipay MV, Brunoni D, de Lourdes Chauffaille M, Verreschi IT. Determination of the sexual phenotype in a child with $45, \mathrm{X}$ / $46, X$, Idic(Yp) mosaicism: importance of the relative proportion of the $45, X$ line in gonadal tissue. Am J Med Genet A. 2006;140A(17):1871-5.

45. Álvarez-Nava F, Soto M, Martínez MC, Prieto M, Álvarez Z. FISH and PCR analyses in three patients with 45,X/46,X,idic(Y) karyotype: clinical and pathologic spectrum. Ann Genet. 2003;46(4):443-8.

46. Lukusa T, Fryns JP. Human chromosome fragility. Biochim Biophys Acta. 2008;1779(1):3-16

47. Sinclair AH, Berta P, Palmer MS, Hawkins JR, Griffiths BL, Smith MJ, et al. A gene from the human sex-determining region encodes a protein with homology to a conserved DNA-binding motif. Nature. 1990:346(6281):240-4.

48. Aktas D, Alikasifoglu M, Gonc N, Senocak ME, Tuncbilek E. Isodicentric Y (p11.32) chromosome in an infant with mixed gonadal dysgenesis. Eur J Med Genet. 2006;49(2):141-9.

49. Codina-Pascual M, Oliver-Bonet M, Navarro J, Starke H, Liehr T, Gutierrez-Mateo $\mathrm{C}$, et al. FISH characterization of a dicentric Yq (p11.32) isochromosome in an azoospermic male. Am J Med Genet A. 2004;127A(3):302-6.

50. Cui YX, Wang WP, Li TF, Li WW, Wu QY, Li N, et al. Clinical and cytogenomic studies in a case of infertility associated with a nonmosaic dicentric $Y$ chromosome. Andrologia. 2015;47(4):477-81.

51. Mekkawy M, Kamel A, El-Ruby M, Mohamed A, Essawi M, Soliman H, et al. Isodicentric $Y$ chromosomes in Egyptian patients with disorders of sex development (DSD). Am J Med Genet A. 2012;158A(7):1594-603.

52. Vogt $\mathrm{PH}$, Edelmann $A$, Hirschmann $P$, Kohler MR. The azoospermia factor (AZF) of the human $Y$ chromosome in Yq11: function and analysis in spermatogenesis. Reprod Fertil Dev. 1995;7(4):685-93.

53. Valetto A, Bertini V, Rapalini E, Baldinotti F, Di Martino D, Simi P. Molecular and cytogenetic characterization of a structural rearrangement of the $Y$ chromosome in an azoospermic man. Fertil Steril. 2004;81(5):1388-90.

54. Jiang $Y$, Wang $R$, Li L, Xue L, Deng S, Liu R. Molecularcytogenetic study of de novo mosaic karyotype 45,X/46,X,i(Yq)/46,X,idic(Yq) in an azoospermic male: Case report and literature review. Mol Med Rep. 2017:16(3):3433-8.

55. Ekici C, Esener Z, Korkmaz S, Salturk N, Yuksel S, Koc A. A Rare Mosaic Karyotype of 45,X/46,X,psu idic(Y)(p11.32)/46,XY with SHOX Haploinsufficiency, External Male Genitalia, and Short Stature. Sex Dev. 2019; 13(1):41-6.

56. Al-Achkar W, Wafa A, Liehr T, Klein E, Moassass F. Detailed analysis of an idic(Y)(q11.21) in a mosaic karyotype. Mol Med Rep. 2012;6(2):293-6.

57. Heinritz W, Kotzot D, Heinze S, Kujat A, Kleemann WJ, Froster UG. Molecular and cytogenetic characterization of a non-mosaic isodicentric $Y$ chromosome in a patient with Klinefelter syndrome. Am J Med Genet A 2005;132A(2):198-201

58. Yoshitsugu K, Meerabux JM, Asai K, Yoshikawa T. Fine mapping of an isodicentric $Y$ chromosomal breakpoint from a schizophrenic patient. Am J Med Genet B Neuropsychiatr Genet. 2003;116B(1):27-31.

59. Mizuguchi T, Hashimoto R, Itokawa M, Sano A, Shimokawa O, Yoshimura Y, et al. Microarray comparative genomic hybridization analysis of 59 patients with schizophrenia. J Hum Genet. 2008;53(10):914-9. 
60. Jagannath $A D$, Rastogi $U$, Spooner $A E$, Lin AE, Agnihotri AK. Aortic dissection and moyamoya disease in Turner syndrome. Am J Med Genet A. 2010;152a(8):2085-9.

61. BouayedAbdelmoula N, Abdelmoula B, Smaoui W, Trabelsi I, Louati R, Aloulou S, et al. Left-sided congenital heart lesions in mosaic turner syndrome. Mol Gen Genomics. 2017;293(2):495-501.

62. Hipp LE, Mohnach LH, Wei S, Thomas IH, Elhassan ME, Sandberg DE, et al. Isodicentric $Y$ mosaicism involving a 46, XX cell line: implications for management. Am J Med Genet A. 2016;170A(1):233-8.

63. Fujimoto A, Boelter WD, Sparkes RS, Lin MS, Battersby K. Monozygotic twins of discordant sex both with 45,X/46,X,idic(Y) mosaicism. Am J Med Genet. 1991;41(2):239-45.

64. Nonomura K, Kakizaki H, Fukuzawa N, Fujieda K, Harada N, Niikawa N, et al. Monozygotic twins with discordant sexual phenotypes due to different ratios of mosaicism of 47,X,idic(Y),idic(Y)/46,X, idic(Y)/45,X. Endocr J. 2002; 49(4):497-501.

65. Seifer DB, Meyers-Seifer CH, Lavy G, Genel M, DeCherney AH, Yang-Feng TL. Laparoscopic adnexectomy in a prepubertal turner mosaic female with isodicentric Y. Hum Reprod. 1991;6(4):566-7.

66. Mizuno K, Kojima Y, Kurokawa S, Mizuno H, Kohri K, Hayashi Y. Laparoscopic diagnosis and treatment of a phenotypic girl with mosaic 45,XO/46, X,idic $(Y)$ mixed gonadal dysgenesis. J Pediatr Surg. 2009:44(1):e1-3.

67. Kawabata G, Sato M, Okamoto Y, Mizuno Y, Akematsu T, Okada H. Laparoscopic removal of gonads in a Turner's syndrome mosaic female patient with isodicentric Y chromosome. Int J Urol. 2000;7(11):425-6.

68. Marrocco G, Poscente M, Majore S, De Bernardo C, Rinaldi R, Del Porto G, et al. Clinical management and molecular cytogenetic characterization in a 45,X/46,X,idic(Yp) patient with severe hypospadia. J Pediatr Surg. 2003;38(8): $1258-62$.

\section{Publisher's Note}

Springer Nature remains neutral with regard to jurisdictional claims in published maps and institutional affiliations.

Ready to submit your research? Choose BMC and benefit from:

- fast, convenient online submission

- thorough peer review by experienced researchers in your field

- rapid publication on acceptance

- support for research data, including large and complex data types

- gold Open Access which fosters wider collaboration and increased citations

- maximum visibility for your research: over $100 \mathrm{M}$ website views per year

At $\mathrm{BMC}$, research is always in progress.

Learn more biomedcentral.com/submissions 